Інноватика у вихованні. Випуск 11. Том 2. 2020.

УДК 378.1

DOI: $\underline{10.35619 / \mathrm{iiu} . v 2 \mathrm{i} 11.229}$

Глінчук Юлія

кандидат педагогічних наук, доцент, доцент кафедри загальнотехнічних дисциплін,

технологій та цивільної безпеки

Рівненського державного гуманітарного університету

м. Рівне, Україна

ORCID: 0000-0003-3328-5594,

e-mail: yuliyaglinchuk@ukr.net

\title{
ФОРМУВАННЯ ПРАЦЕОХОРОННОЇ СПРЯМОВАНОСТІ У МАЙБУТНІХ УЧИТЕЛІВ ПОЧАТКОВИХ КЛАСІВ ШЛЯХОМ ПРОФЕСІЙНОЇ ЗОРІЕНТОВАНОСТІ ЗМІСТУ НАВЧАННЯ 3 «ОХОРОНИ ПРАЦІ В ГАЛУЗІ»
}

Анотація. У статті актуалізується проблема втрати здоров'я учнів та вчителів у шкільному загальноосвітньому середовищі. Зазначається, що така ситуація зумовлена сукупною дією різних освітніх та суспільних чинників, однак однією з основоположних причин є недостатня працеохоронна спрямованість майбутніх учителів початкових класів як сукупність цінностей та мотивів, що визначають алгоритми поведінки щодо збереження життя, здоров'я та працездатності суб'єктів навчально-виховного процесу. Звертається увага на те, що вагомою проблемою у контексті формування працеохоронної спрямованості майбутніх учителів початкових класів $є$ недостатня професійна зорієнтованість змісту навчання 3 «Охорони праці в галузі».

Визначається професійно-зорієнтований зміст навчання 3 «Охорони праці в галузі» на основі врахування законодавчих та нормативних документів, що регламентують збереження життя, здоров'я та працездатність суб'єктів освітньо-виховного процесу, негативних виробничих чинників загальноосвітнього шкільного середовища, можливих векторів майбутньої професійної діяльності, наявних наукових та методичних розробок щодо збереження життя, здоров'я та працездатності суб'єктів освітньо-виховного процесу. Доведено позитивний вплив професійно-зорієнтованого змісту навчання із «Охорони праці в галузі» на працеохоронну спрямованість майбутніх учителів початкових класів.

Ключові слова: учні, вчителі, здоров'я, майбутні учителі початкових класів, працеохоронна спрямованість, зміст навчання.

Постановка проблеми. Дані детального дослідження стану здоров'я сучасних школярів та чинників, що на нього впливають, засвідчують значне погіршення здоров'я підростаючого покоління за період навчання у школі. Саме за цей період реєструється найвища поширеність захворювань та накопичення хронічної патології. Причому, упродовж останніх років здоров'я дітей та підлітків залишається незадовільним при негативній тенденції (Міністерство охорони здоров'я, 2015, с. 35-60).

Найчастіше втрата здоров'я внаслідок дії негативних освітніх чинників спостерігається серед учнів початкових класів: уже на кінець першого класу кількість абсолютно здорових дітей зменшується 3 10,1 \% до 3,8 \%, кількість дітей із функціональними відхиленнями - 3 59,7 \% до 46,2 \%, проте кількість дітей із хронічною захворюваністю збільшується із 30,2 \% до 49,4 \% (Міністерство охорони здоров'я, 2017, с. 53). Резонуючим чинником при цьому 
виступає проблема учнівського травматизму, особливо серед молодших школярів, які є найбільш травмонебезпечною категорією (Родіонов та Ступницька, 2009).

Водночас проблема втрати здоров'я $є$ актуальною й щодо інших учасників навчальновиховного процесу - педагогів, рівень здоров'я переважної більшості яких оцінюється як критичний (Зоріна, 2013). Крім цього, саме шкільні вчителі очолюють десятку «свідомих алкоголіків» - тих, хто має алкогольну залежність, але усвідомлює необхідність позбавлення від неї (ТОП-10.., 2010).

Безперечно, що така прикра ситуація зумовлена сукупною дією різних освітніх та суспільних чинників, однак, однією з основоположних причин, на наш погляд, є недостатня працеохоронна спрямованість учителів як сукупність цінностей та мотивів, що визначають алгоритми поведінки щодо збереження життя, здоров'я та працездатності суб'єктів навчально-виховного процесу. Адже саме цінності та мотиви виступають спрямовуючою силою діяльності індивіда (Ільїн, 2000).

Попередньо нами було з'ясовано, що зміст навчання 3 «Охорони праці в галузі» для студентів педагогічних спеціальностей вирізняється недостатньою професійною зорієнтованістю. Це передусім пов'язано з відносним нововведенням цієї дисципліни, переважно інженерною, а не інженерно-педагогічною чи педагогічною освітою викладачів, недостатньою кількістю необхідної літератури і т. п. На практиці це призвело до автоматичного перенесення змісту навчального матеріалу із відповідного курсу, який викладався для підготовки фахівців інженерної, промислової, економічної та інших галузей (Глінчук, 2014).

Аналіз останніх досліджень проблеми. Проблема змісту навчання у підготовці фахівця знаходиться в полі зору багатьох вчених.

Наприклад, О. Савченко зазначає, що саме зміст освіти є системотворчим компонентом навчального процесу, базисом освіченості і культури всього населення (Савченко, 2001).

На думку В. Єфімової, у вирішенні проблеми здоров'язбереження школярів фундаментальна роль належить змісту навчання студентів педагогічних спеціальностей (Сфімова, 2010).

На важливості оволодіння студентами професійно орієнтованими знаннями у контексті формування їх ціннісних орієнтацій наголошує В. Денисенко (Денисенко, 2005).

Про необхідність врахування сфери майбутньої професійної діяльності при вдосконаленні планування 3 дисципліни «Охорона праці в галузі» зазначають А. Русаловський, С. Селіванов (Русаловський та Селіванов, 2004) і О. Боженов (Боженов, 2014).

Окремі аспекти проблеми здоров'язбереження школярів розкриті в дослідженнях Р. Білик, О. Бондаренко, С. Боровської, О. Кобилянського, В. Комарова, Г. Коржа, В. Кошкіна, Г. Кривошеєва, В. Рацслав, О. Тимощук та ін.).

Однак, як засвідчує аналіз літературних джерел, на сьогодні означена проблема $є$ недостатньо дослідженою.

Мета статті - теоретично обгрунтувати професійно-зорієнтований зміст навчання 3 дисципліни «Охорона праці в галузі» та висвітлити результати експериментальної перевірки впливу професійно-зорієнтованого змісту навчання 3 дисципліни «Охорона праці в галузі» на працеохоронну спрямованість майбутніх учителів початкових класів.

Виклад основного матеріалу дослідження. Професійно зорієнтований зміст працеохоронного навчання майбутніх учителів початкових класів здійснювався шляхом врахування: 
- законодавчих актів, що регламентують збереження життя, здоров'я та працездатності суб'єктів освітньо-виховного процесу (Закони України «Про освіту», «Про загальну середню освіту», «Про охорону дитинства», Національна доктрина розвитку освіти України, Державна Національна програма «Освіта», Національна програма виховання дітей та учнівської молоді в Україні; Концепція «Здоров’я через освіту», Концепція формування позитивної мотивації на здоровий спосіб життя, Концепція неперервної валеологічної освіти та ін.);

- нормативно-правових актів для закладів освіти (ДСАНПіН «Влаштування, утримання, загальноосвітніх навчальних закладів та організації навчально-виховного процесу», ДСАНПіН «Влаштування і обладнання кабінетів комп'ютерної техніки в навчальних закладах та режим праці учнів», накази, положення, інструктивно-методичні листи Міністерства освіти і науки України з питань збереження життя, здоров'я та працездатності суб'єктів освітньо-виховного процесу);

- виробничих чинників шкільного освітнього середовища (санітарно-гігієнічних, психофізіологічних, естетичних, соціально-психологічних);

- можливих векторів професійної працеохоронної діяльності майбутніх педагогів: учитель, завідувач кабінету, класний керівник, управлінець, член трудового колективу (профспілкової організації), делегат трудового колективу (профспілкової організаціі), голова трудового колективу (профспілкової організації) та ін.;

- наявних наукових та методичних розробок щодо збереження життя, здоров'я та працездатності суб'єктів навчально-виховного процесу (освітні здоров'явідповідні та здоров'язбережувальні технології, технології попередження учнівського травматизму, технології попередження професійних розладів і захворювань педагогічних працівників та ін.) (Hlinchuk, 2019).

На основі цього було розроблено та реалізовано професійно-зорієнтовану робочу навчальну програму дисципліни «Охорона праці в галузі».

Педагогічним експериментом було охоплено 90 студентів денної форми навчання спеціальності «Початкова освіта», яких було розділено на контрольну групу (КГ) та експериментальну групу (ЕГ). До контрольної групи увійшли студенти, яким викладалась дисципліна «Охорона праці в галузі» без цілеспрямованого забезпечення професійної зорієнтованості змісту навчання (45 осіб жіночої статі); а до експериментальної - студенти, яким викладалась дисципліна «Охорона праці в галузі» із цілеспрямованим забезпеченням професійної зорієнтованості змісту навчання (45 осіб жіночої статі).

Дослідження здійснювалося впродовж 2015-2017 років на базі Рівненського державного гуманітарного університету.

Стратегія дослідження передбачала вивчення працеохоронної спрямованості майбутніх учителів початкових класів у якісному та кількісному вимірах.

Для діагностики якісного виміру ми застосували психолого-педагогічне спостереження, неформальне спілкування та здійснили аналіз результатів діяльності студентів. Було виявлено, що в експериментальній групі після ознайомлення студентів 3 професійною складовою навчальної дисципліни та статистичними даними, що стосувалися стану здоров'я учнів та вчителів, колективного обговорення впливу загальноосвітнього шкільного середовища на його суб'єктів помітно зросла пізнавальна активність студентів: вони висловлювали свою думку, доводили точку зору, наводили приклади, шукали аналогії та порівнювали. Студенти продовжували ставити запитання та обговорювати запропоновані ситуації і по завершенню заняття, звертались за індивідуальною консультацією, ініціюючи неформальне спілкування. 
Якщо у контрольній групі підготовленість студентів до практичних занять мала виражені ознаки формальності, то в експериментальній - ознаки інтересу та ентузіазму.

Для діагностики кількісного виміру нами було застосовано адаптовану методику Б. Басса «Діагностика професійної спрямованості особистості», яка дозволила визначити показники спрямованості особистості за трьома напрямами:

- спрямованість на себе - орієнтація на винагороду та задоволення, агресивність у досягненні статусу, схильність до суперництва, тривога, роздратованість, прагнення влади;

- спрямованість на інших - прагнення підтримувати стосунки з людьми, орієнтація на спільну діяльність (не обов'язково для виконання справи, а й заради спілкування); орієнтація на соціальне схвалення, залежність від соціальної групи, потреба в емоційних взаєминах;

- спрямованість на справу - зацікавлення у вирішенні професійних проблем, виконанні роботи якнайкраще; орієнтація на ділову співпрацю, здатність відстоювати заради справи власну точку зору, корисну для досягнення загальної мети.

Застосування даної методики засвідчило, що працеохоронна спрямованість на себе проявляється в 44,44 \% студентів КГ і 26,63 \% студентів ЕГ, на інших - в 26,63 \% студентів КГ і 22,22 \% студентів ЕГ, на справу - в 28,93 \% студентів КГ і 48,15\% студентів ЕГ (рис. $1)$.

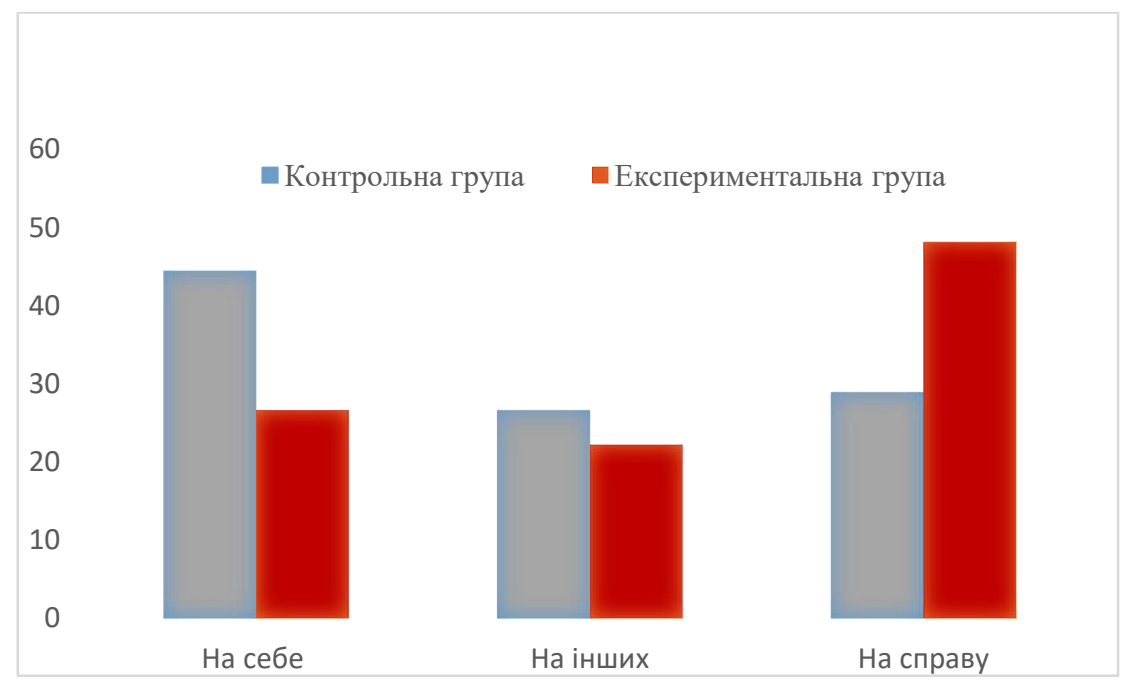

\section{Рисунок 1. Працеохоронна спрямованість майбутніх учителів початкових класів}

Таким чином, з'ясовано, що у контрольній групі домінує спрямованість на себе, а в експериментальній - спрямованість на справу. Водночас, у експериментальній групі нижчі показники спрямованості на себе та інших.

Висновки i перспективи подальших розвідок. Вищезазначене дає підставу стверджувати, що професійна зорієнтованість змісту навчання 3 «Охорони праці в галузі» має безпосередній позитивний вплив на працеохоронну спрямованість майбутніх учителів початкових класів. 
Перспективи подальших досліджень ми вбачаємо у дослідженні впливу професійнозорієнтованого змісту навчання 3 «Охорони праці в галузі» на рівень знань студентів 3 цієї дисципліни.

\section{СПИСОК ВИКОРИСТАНИХ ДЖЕРЕЛ}

Міністерство охорони здоров'я України (2015). Щорічна доповідь про стан здоров'я населення, санітарно-епідеміологічну ситуацію та результати діяльності системи охорони здоров'я України. Київ : ДУ «УІСД МОЗ України». 460 с.

Міністерство охорони здоров'я України (2017). Щорічна доповідь про стан здоров'я населення, санітарно-епідеміологічну ситуацію та результати діяльності системи охорони здоров'я України. Київ : ДУ «УІСД МОЗ України». 516 с.

Родионов, В. и Ступницкая, М. (2009) Причины детского травматизма. Справочник руководителя образовательного учреждения. Специиальный выпуск «Профилактика травматизма в школе», 13. URL: https://www.menobr.ru/news/6169-elektronnaya-versiyaspetsvypuska-profilaktika-travmatizma-v-shkole: [Дата обращения 20 марта 2020].

Зоріна, М. (2013). Професійне здоров'я вчителя як важлива складова його діяльності. Педагогіка формування творчої особистості у вищій $i$ загальноосвітній школах. 33 (86). c. 175-179.

ТОП-10 питущих професій (2010). Директор школи Украӥни. 5. с. 62.

Ильин, Е. (2000). Мотивация и мотивы. Санкт-Петербург : «Издательство Питер», 546 с.

Глінчук, Ю. (2014). Проблеми та суперечності при формуванні компетентності 3 охорони праці в галузі у майбутніх учителів початкових класів. В: «Science offuture». Prague. p. 239-246.

Савченко, О. (2001). Удосконалення професійної підготовки майбутніх учителів початкових класів. Початкова школа. 7. с. 1-4.

Єфімова, В. (2010). Особливості здоров'язбережувальної діяльності вчителя загальноосвітнього навчального закладу в сучасних умовах. Педагогіка, психологія та медико-біологічні проблеми фізичного виховання і спорту. 11. с. 38-41.

Денисенко, В. (2005). Формування ціннісних орієнтацій майбутніх учителів початкових класів. Кандидат педагогічних наук. Харківський національний педагогічний університет імені Г. С. Сковороди.

Русаловський, А. та Селіванов, С. (2004). Актуальні питання планування нормативних дисциплін «Безпека життєдіяльності», «Цивільна оборона», «Основи охорони праці», «Охорона праці в галузі» у вищих навчальних закладах. Вестник Харьковского национального автомобильно-дорожного университета. 26. с. 89-93.

Боженов, О. (2014). Особливості розробки навчальних планів і програм для вивчення питань охорони праці. Охорона праці. 4 (235). с. 24.

Hlinchuk, Yu. (2019). The influence of profession-oriented syllabus of "Occupational safety in the field" on the motivation of future primary school teachers to prepare for the provision of pupils' physical activity. International Journal of Innovative Technology and Exploring Engineering. 8 (9). p. 1317-1324.

\section{REFERENCE}

Ministerstvo okhorony zdorovia Ukrainy (2015). Shchorichna dopovid pro stan zdorovia naselennia, sanitarno-epidemiolohichnu sytuatsiiu ta rezultaty diialnosti systemy okhorony zdorovia Ukrainy [Annual Report on the State of Health of the Population, the Sanitary- 
epidemiological Situation and the Results of Activity of the Health Care System of Ukraine]. Kyiv : DU "UISD MOZ Ukrainy". 460 s. (in Ukrainian).

Ministerstvo okhorony zdorovia Ukrainy (2017). Shchorichna dopovid pro stan zdorovia naselennia, sanitarno-epidemiolohichnu sytuatsiiu ta rezultaty diialnosti systemy okhorony zdorovia Ukrainy [Annual Report on the State of Health of the Population, the Sanitaryepidemiological Situation and the Results of Activity of the Health Care System of Ukraine]. Kyiv : DU “UISD MOZ Ukrainy". 516 s. (in Ukrainian).

Rodionov, V. i Stupnitskaya, M. (2009) Prichiny detskogo travmatizma [Causes of Childhood Injuries]. Spravochnik rukovoditelya obrazovatelnogo uchrezhdeniya. Spetsialnyy vypusk "Profilaktika travmatizma $v$ shkole", 13. URL: https://www.menobr.ru/news/6169-elektronnayaversiya-spetsvypuska-profilaktika-travmatizma-v-shkole: [Data obrashcheniya 20 marta 2020]. (in Russian).

Zorina, M. (2013). Profesiine zdorovia vchytelia yak vazhlyva skladova yoho diialnosti [Vocational Health of a Teacher as Important Component of his Activity]. Pedahohika formuvannia tvorchoi osobystosti u vyshchii i zahalnoosvitnii shkolakh. 33 (86). s. 175-179. (in Ukrainian).

TOP-10 pytushchykh profesii [TOP 10 Drinking Professions] (2010). Dyrektor shkoly Ukrainy. 5. s. 62. (in Ukrainian).

Ilin, E. (2000). Motivatsiya i motivy [Motivation and Motives]. Sankt-peterburg: "Izdatelstvo Piter", 546 s. (in Russian).

Hlinchuk, Yu. (2014). Problemy ta superechnosti pry formuvanni kompetentnosti z okhorony pratsi v haluzi u maibutnikh uchyteliv pochatkovykh klasiv [Challenges and Contradictions in the Formation of Competency in Occupational Safety in Future Elementary School Teachers]. V: "Science of future". Prague. s.239-246. (in Ukrainian).

Savchenko, O. (2001). Udoskonalennia profesiinoi pidhotovky maibutnikh uchyteliv pochatkovykh klasiv [Improving the Professional Training of Future Elementary School Teachers]. Pochatkova shkola. 7. s. 1-4. (in Ukrainian).

Yefimova, V. (2010). Osoblyvosti zdoroviazberezhuvalnoi diialnosti vchytelia zahalnoosvitnoho navchalnoho zakladu v suchasnykh umovakh [Peculiarities of Health-saving Activity of a Teacher of a General Educational Institution in Modern Conditions]. Pedahohika, psykholohiia ta medyko-biolohichni problemy fizychnoho vykhovannia i sportu. 11. s. 38-41. (in Ukrainian).

Denysenko, V. (2005). Formuvannia tsinnisnykh oriientatsii maibutnikh uchyteliv pochatkovykh klasiv [Formation of Value Orientations of Future Elementary School Teachers]. Kandydat pedahohichnykh nauk. Kharkivskyi natsionalnyi pedahohichnyi universytet imeni H. S. Skovorody. (in Ukrainian).

Rusalovskyi, A. ta Selivanov, S. (2004). Aktualni pytannia planuvannia normatyvnykh dystsyplin "Bezpeka zhyttiediialnosti", "Tsyvilna oborona", "Osnovy okhorony pratsi", "Okhorona pratsi v haluzi" u vyshchykh navchalnykh zakladakh [Topical Issues of Planning the Regulatory Disciplines "Life Safety“, "Civil Defense", "Fundamentals of Occupational Safety", "Occupational Safety" in Higher Education Institutions]. Vestnyk Kharkovskogo natsyonalnogo avtomobilno-dorozhnogo universiteta. 26. s. 89-93. (in Ukrainian).

Bozhenov, O. (2014). Osoblyvosti rozrobky navchalnykh planiv i prohram dlia vyvchennia pytan okhorony pratsi [Features of the Development of Curricula and Programs for the Study of Safety Issues]. Okhorona pratsi. 4 (235). s. 24. (in Ukrainian).

Hlinchuk, Yu. (2019). The Influence of Profession-oriented Syllabus of "Occupational Safety in the Field" on the Motivation of Future Primary School Teachers to Prepare for the Provision of 
Pupils' Physical Activity. International Journal of Innovative Technology and Exploring Engineering. 8 (9). p. 1317-1324.

\title{
FORMATION OF PROFESSIONAL DIRECTION IN FUTURE ELEMENTARY SCHOOL TEACHERS BY MEANS OF PROFESSIONAL ORIENTATION OF THE TRAINING CONTENT IN THE DISCIPLINE "PROFESSIONAL SAFETY IN THE FIELD”
}

\author{
Yuliia Hlinchuk \\ Candidate of Pedagogical Sciences, Associate Professor, \\ Associate Professor at the Department \\ of General Technical Disciplines, Technologies and Public Safety, \\ Rivne State University for the Humanities, \\ Rivne, Ukraine \\ yuliyaglinchuk@ukr.net \\ ORCID: 0000-0003-3328-5594 \\ e-mail: yuliyaglinchuk@ukr.net
}

\begin{abstract}
The article deals with the problem of loss of health of students and teachers in the school-wide environment. It is noted that this situation is caused by the cumulative effect of various educational and social factors, but one of the fundamental reasons is the lack of work orientation of future elementary school teachers as a set of values and motives that determine behavior algorithms for preserving life, health and ability to educational process. Attention is paid to the fact that a major problem in the context of the formation of future elementary school teachers professional direction on occupational health there is a lack of professional orientation of the content from the "Occupational Safety in the field".

The article defines the professional-oriented content of training in "Occupational Safety in the field", based on the consideration of legislative and regulatory documents that regulate the preservation of life, health and working capacity of subjects of the educational process, negative production factors of the general school environment, possible activities of future professions, available scientific and methodological developments for the preservation of life, health and efficiency of the subjects of the educational process.

The results of the study of the impact of professional orientation content of training in "Occupational Safety in the field" on the occupational orientation of future elementary school teachers in three areas were described: orientation on yourself (focus on direct reward and satisfaction, aggressiveness in achieving superannuation, irritation, desire for power); orientation on others (the desire to maintain a hundred relationships with people, an orientation to working together, including for the sake of communication itself, an orientation to social acceptance, dependence on a social group, the need for emotional relationships); orientation on the business (interest in solving professional problems, doing the best work possible, focusing on business cooperation, the ability to defend in the interests of the case their own opinion, useful for achieving a common goal).

The positive influence of the vocationally-oriented content of the "Occupational Safety in the field" on the professional direction on occupational health of future primary school teachers is claimed.
\end{abstract}

Keywords: pupils, teachers, health, future elementary school teachers, work orientation, content of training. 